\title{
Environmental Literacy: Indigenizing Environmental Education
}

\author{
Norshariani Abd Rahman', Nurfaradilla Mohamad Nasri ${ }^{2}$ \\ ${ }^{1}$ Institut Islam Hadhari, Universiti Kebangsaan Malaysia, Bandar Baru Bangi, Malaysia \\ ${ }^{2}$ Faculty of Education, Universiti Kebangsaan Malaysia, Bandar Baru Bangi, Malaysia \\ Email: norshariani@ukm.edu.my, nurfaradilla@ukm.edu.my
}

How to cite this paper: Abd Rahman, N., \& Nasri, N. M. (2018). Environmental Literacy: Indigenizing Environmental Education. Creative Education, 9, 2148-2160. https://doi.org/10.4236/ce.2018.914156

Received: August 16, 2018

Accepted: October 26, 2018

Published: October 29, 2018

Copyright (c) 2018 by authors and Scientific Research Publishing Inc. This work is licensed under the Creative Commons Attribution International License (CC BY 4.0).

http://creativecommons.org/licenses/by/4.0/

\begin{abstract}
Inculcating awareness in preserving the environment among citizens is important. Thus Environmental Education (EE) was introduced as a compulsory subject for all Malaysian students including Aboriginal community. However, many researchers have reported that indigenous knowledge (IK) with regards to environment education received less attention by researchers although many researchers have suggested that IK greatly influenced the understanding, as well as the behaviour of the Aboriginal people in preserving and conserving the environment. This study aims to investigate the effect of gender, education level and tribes on environmental literacy among Aboriginal community in Pahang, Malaysia. This study adopted a survey research design where data were collected using two research instruments which are knowledge test and questionnaire to examine their knowledge and behaviour towards protecting the environment. Findings indicate that the level of environmental knowledge among Malaysian Aboriginal people is at a moderate level while their behaviours towards environmental care are at low moderate level most probably because the formal EE curriculum at school does not relate well with their IK. Therefore, it is suggested that Malaysian EE curriculum should be revised to creatively acknowledge and integrate IK to ensure its relevancy to Aboriginal communities.
\end{abstract}

\section{Keywords}

Aboriginal, Environment, Preserving, Conserving, Behaviour

\section{Introduction}

Society nowadays is not managing the environment responsibly and is becoming more aggressive in exploiting nature without thinking about future generation (Yusuf, Ibrahim, Sulaiman, \& Mamat, 2005) thus causing natural resources to be 
depleted and unbalanced (Aziz, 2008). Environmental disasters such as plants and animals species' extinction, landslides, erosion, flash floods, global warming, depletion of the ozone layers, haze, air pollution, river and sea pollution prove the impacts of human's irresponsible actions towards the environment.

Ethical action is an important asset that every individual should instill within themselves to preserve the quality of environment in line with the country's development (Hungerford, Bluhm, Volk, \& Ramsey, 2005). Thus, countless efforts are taken to increase the awareness and actions in protecting the environment locally and globally. For the local stage, the government's concerns towards environmental issues are integrated in the national development blueprint and the government's policies. This was further proved with the creation of the National Policy on the Environment in 2002 adhering to the 8 principles in harmonizing the economic development goals with environmental importance (Department of Environment, 2007).

At a global stage, a few series of international conferences were held to discuss on environmental issues. Among them were the Belgrade Conference, Tbilisi Conference and Earth Summit (Palmer, 1998). The main objective of these conferences is to nurture citizens with positive knowledge, awareness, behaviours, skills and actions in preserving the environment (Department of Environment, 2007; Palmer, 1998). Due to the sequence of these series, Environmental Education was introduced to inculcate awareness in protecting the environment (Department of Environment, 2007; Palmer, 1998; bin Ab Hadi, bin Mohd Yunos, \& bin Esa, 2003; Stapp, 1969).

Environmental education is a compulsory subject for all Malaysian students, thus the Aboriginal community is not excluded from receiving the subject. Besides that, the Aboriginal community plays a vital role in the preservation of the environment (Hungerford \& Volk, 1990) because they are the closest society with the environment (United Nations, 1992; Chopil \& Hunt, 2009; Mian, 1997; Nicholas \& Lasimbang, 2004; Ismail, 2004; Jelas, Ahmad, \& Ayudin, 2009).

However, as a result of rapid progression, several young generations of Aboriginal are no longer living in the forest and are no longer running traditional economy by collecting resources from the forest. They are being grouped together in one district and practice modern agriculture through the support from the government (Department of Orang Asli Development (DOAD), 2009). The rapid progression achieved by the Aboriginal community can be seen not only through their economical change, but their social and way of thinking as well. The changes of lifestyle that the Aboriginal community is currently going through will also influence their knowledge towards the environment (Hines, Hungerford, \& Tomera, 1986/1987; Kollmuss \& Agyeman, 2002). Thus, a study needs to be conducted to identify the extent to which indigenous knowledge is integrated and influence Aboriginal's knowledge and behaviour to ensure the preservation of the environment. 


\section{Literature Review}

As has been agreed during the Earth Summit Conference in Rio de Janeiro in 1992 (United Nations, 1992), Aboriginal community has an important role in conserving and preserving the environment. Since they are one of the communities that depend on nature as a source of economic livelihood (Mian, 1997; Jelas, Ahmad, \& Ayudin, 2009; Hood, 2012), hence their environmental literacy needs to be assessed and strengthen.

In the past, Aboriginal only used natural resources for their own needs. However, due to commercial demands, they were being exploited to gather natural resource such as plants and exotic animals that have medicinal as well as economic value (Nicholas \& Lasimbang, 2004). Furthermore, through Rancangan Pengumpul Semula (RPS), Aboriginals were given land for cultivation of oil palm and rubber. As a result, a great majority of Aboriginals has abandoned their old agricultural methods and traditions. Hence, the decline in IK especially knowledge about traditional environmental management has become eroded (Nicholas \& Lasimbang, 2004).

The declining of IK being transferred from the older generation to the new generation of Aboriginal people caused the younger generation to have lower environmental knowledge. This claim is well supported by a study conducted by (Yusuf, Ibrahim, Sulaiman, \& Mamat, 2005) who found that the level of environmental knowledge among Aboriginal secondary school students in Pahang is significantly low. Their findings also indirectly indicate some flaw in the implementation of formal Environmental Education (EE) at school especially among Aboriginal where EE failed to increase the Aboriginal students' environmental knowledge. A point to note, knowledge of the environment is fundamental particularly in shaping one's attitudes and changing one's behaviour towards environmentally friendly users (Hines, Hungerford, \& Tomera, 1986/1987; Elder, 2003; Ramsey \& Rickson, 1976).

However, (Yusuf, Ibrahim, Sulaiman, \& Mamat, 2005) study focuses only on environmental knowledge per se. Hines, Hungerford, \& Tomera, (1986/1987) and Emmons (1997) emphasizes that in predicting responsible behaviour towards the environment, the element of knowledge action towards environment is also important. Therefore, this study takes into considerations the element of knowledge in choosing the action towards the environment based on various environmental issues to investigate the level of environmental knowledge possess by Aboriginal students.

A study conducted by Haliza (2010) on the participation of the Aboriginal people on environmental issues revealed that the level of awareness and involvement of Aboriginal people can be divided into three distinctive groups. The first group refers to those who are interested in environmental issues but is not actively engaged in related activities. The second group is the ones who are not concerned about environmental issues but supports the efforts of conserving and preserving the environment. While the third is the neutral group, they are less 
interested to an extent they never bother about environmental issues and cares.

Haliza (2010) continues to conclude that the awareness and participation of Aboriginal people in environmental related actions is inadequately low and worrying. It should be noted that urbanization, economic growth, infrastructure development, unlimited internet and mass media access have greatly influenced the way Aboriginal people thinks and acts (Chopil \& Hunt, 2009). Therefore, it is necessary to study environmental literacy of the Aboriginal people by focusing on the knowledge as well as behaviour towards environment. This can illustrate how younger generations of the Aboriginal people think and act with regards to environmental issues despite social and economic changes. Furthermore, findings of this study provide an important insight on how to effectively deliver EE to meet the needs of Aboriginal people.

\section{Methodology}

This study adopted a survey research design. Data is collected using two research instrument which are knowledge test and questionnaire. This study involved Aboriginal primary and secondary school students in Pahang, Malaysia. Pahang was chosen as the research site because it has the largest population of Aboriginal people in Malaysia $(n=67506)$ and their lifestyle is more modern than other Aboriginal people in other states (Department of Orang Asli Development (DOAD), 2009).

\subsection{Sampling}

This study uses stratified random sampling on 450 Aboriginal primary and secondary school students in Pahang. Student selection is assisted by their teachers in identifying students with good reading ability which may enable them to answer the questionnaire accordingly. Of the 450 questionnaires distributed, only 445 ( $n=250$, primary school students, $n=195$, secondary school students) students returned the completed questionnaire. Respondents for primary school students are taken from fifth and sixth graders (11 - 12 years old) because at this stage, more students are able to read while secondary school students are taken from lower secondary students (13 - 14 years old). In terms of gender, $32.5 \%$ are males while $65.7 \%$ are females. However, for the purposes of the inferential statistical analysis, only 428 respondents were involved in this study as data from 17 respondents could not be used due to the presence of outliers.

\subsection{Research Instrument}

The research instrument used in this study was developed by researchers based on the Environmental Education Across Curriculum Guidebook published by the Ministry of Education Malaysia (Ministry of Education, Malaysia, 1998) and adaptation of questionnaires developed by earlier researchers which are related to the constructs being investigated. This self-developed instrument was ap- 
proved and certified by three experts in the field of environmental education, moral education and urban development.

This instrument has been meticulously developed and adapted by focusing on the aspects of: 1) environmental knowledge and 2) environmental action knowledge. Environmental knowledge test was also developed by the researchers based on the Environmental Education Across Curriculum guidebook, while the environmental action knowledge test was adopted from (Goldman, Yavetz, \& Pe'er, 2006) questionnaire which stresses on alternative Aboriginal behaviours in relation to various environmental issues.

There are 12 test questions on environmental knowledge and 8 test questions on environmental action knowledge. For analysis purposes, the amount of environmental knowledge scores and environmental action knowledge is divided by five Likert scales. The value of Kuder-Richardson for environmental knowledge is $0-604$.

The environmental behaviour construct was assessed with the frequency of action to prevent environmental problems associated with the lifestyle of Aboriginal people. These behaviours include their involvement in environmental activities related to river care, preservation of animals and plants, solid waste management as well as practices to enhance environmental knowledge. The value of alpha Cronbach for environmental behaviours is 0.882 .

\subsection{Data Collection Procedure}

For data collection purposes, researchers obtain prior permission from the Ministry of Education (MOE) to carry out research. Upon approval by MOE, tests and questionnaires are sent by post, accompanied by a letter of application to conduct research at school, a letter of consent to conduct research from the Ministry of Education (MOE), the envelope and the address of the main researcher or the purpose of reposting the completed questionnaires as well as some souvenirs as a token of appreciation for respondents.

\subsection{Data Analysis Procedure}

The data were analysed using descriptive and inferential statistic. Descriptive analysis in used to describe the overall profile of respondent such as education level, gender, and ethnicity in order to identify their level of knowledge on environment as well as behaviour towards environmental care. The descriptive statistics used are percentage of mean score and standard deviation. Next, environmental knowledge test is interpreted based on the minimum score used by the Ministry of Education (MOE), in assessing students' performance in examinations, in assessing students' performance in examinations. The mean score interpretation used in illustrated in Table 1.

To interpret behaviour factor towards environmental care, the amount of the obtained score will be converted to mean as it would best facilitate the interpretation of mean. The mean score interpretation used in this study is based on 
Table 1. Mean score interpretation for Environmental.

\begin{tabular}{cc}
\hline Mean Score (\%) & Minimum score interpretation \\
\hline $80-100$ & Excellent \\
$65-79$ & Good \\
$50-64$ & Moderate \\
$40-49$ & Poor \\
$0-39$ & Fail \\
\hline
\end{tabular}

Source: Ministry of Education, 2012.

(Nunnally, 1997) as shown in Table 2. Inferential data involves a one-way MANOVA analysis and t-test. The data were analyzed using SPP version 2.0.

\section{Findings}

This section is divided into five section and each section serves to answer the research question which serves as a guide in designing the data collection as well as data analysis procedure.

\subsection{Environmental Knowledge Level of Aboriginal School Students}

The knowledge level in this study is measured based on two aspects; environmental knowledge and the environmental action knowledge. Questions used in the environmental knowledge test focuses only on environmental issues which are closely related to the lifestyle of the Aboriginal people such as the issue of river pollution, the extinction of plants and animals and solid waste management.

Based on Table 1, in general, the level of knowledge among Aboriginal school students is at a good level with a mean score of $66.49 \%$ (s.d. $=0.178$ ). However, it is important to highlight that not all element in environmental knowledge are at a good level. The mean score of environmental knowledge element is $58.79 \%$ (s.d. $=0.218)$ which indicates that the level of knowledge is at moderate level while the level of environmental action knowledge is at a good level with mean score of $77.50 \%$ (s.d. $=0.199)($ Table 3$)$.

\subsection{The Level of Environmental Care Behaviour among Aboriginal School Students}

In this study, the behavioural level of Aboriginal school students comprises of fine practices which are closely related to the lifestyle of Aboriginal people, namely river care, preventing the extinction of animal, preventing the extinction of plant species, solid waste management and routine practices that enhance the knowledge on environmental issues. Overall, the behaviour of Aboriginal school students on environmental care practices was at moderate low level with mean value $=2.907$ and standard deviation $=0.912$. 
Table 2. Mean score interpretation for Behaviour construct towards Environment Care.

\begin{tabular}{cc}
\hline Mean Score (\%) & Interpretation of Mean Score \\
\hline $1.00-2.00$ & Low \\
$2.01-3.00$ & Moderate low \\
$3.01-4.00$ & Moderate high \\
$4.01-5.00$ & High \\
\hline
\end{tabular}

Source: Nunnally (1997).

Table 3. Mean score and standard deviation for knowledge construct,

\begin{tabular}{cccc}
\hline $\begin{array}{c}\text { Element in Knowledge } \\
\text { Construct }\end{array}$ & Mean Score (\%) & Standard Deviation & $\begin{array}{c}\text { Interpretation of } \\
\text { Mean Score }\end{array}$ \\
\hline $\begin{array}{c}\text { Environmental Knowledge } \\
\text { Environmental Action } \\
\text { Knowledge }\end{array}$ & 58.79 & 0.218 & Moderate \\
$\begin{array}{c}\text { Knowledge about } \\
\text { Environment }\end{array}$ & 77.50 & 0.199 & Good \\
\hline
\end{tabular}

Further analysis revealed that only one element in environmental care behaviours which is preventing the extinction of animal (mean $=3.054$, s.d. $=1.145$ ) is at moderate high level. While the other four elements, the routine practices that enhance the environmental knowledge (mean $=2.94$, s.d $=1.095)$, solid waste management $($ mean $=2.847$, s.d. $=1.171)$, preventing the extinction of plant species $($ mean $=2.782$, s.d. $=1.465)$, are at low moderate levels. A summary of the findings of the environmental care behaviour among Aboriginal people is shown in Table 4.

\subsection{Differences in Environmental Knowledge Level and Behaviours Based on Education Level}

Table 5 shows the findings of MANOVA's analysis of the difference in knowledge and behaviour constructs among primary and secondary Aboriginal school students. After obtaining a significant result in the multivariate test, the Test of the between-subject effects was referred and the results of the analysis showed a comparative analysis made on a recurring basis.

To reduce the error of Type 1 due to repeated analysis, Alpha Bonferroni modification method was used (Hair et al., 2010). Table 6 shows a significant difference based on Alpha Bonferroni $(0.05 / 3)=0.017$ level in knowledge constructs between primary and secondary students whose value is $\mathrm{F}=23.219, \mathrm{p}=$ 0.000 , partial eta squared $(\mathrm{y} 2)=0.052$. Mean scores for environmental knowledge elements towards that the mean score of secondary school students (mean $=0.6484)$ was higher than primary school students (mean $=54.04)$. However, there was no significant differences in the constructs of behaviour $(F=2.103, p$ $=0.148$, partial eta squared $(\mathrm{n} 2)=0.005)$ based on school level. 
Table 4. Mean and standard deviation for elements in environmental care behaviour.

\begin{tabular}{cccc}
\hline $\begin{array}{c}\text { Element in Behaviour } \\
\text { Construct }\end{array}$ & Mean & Standard Deviation & Mean Interpretation \\
\hline $\begin{array}{c}\text { Extinction of Animal } \\
\text { Routine Practices to Enhance } \\
\text { Environmental Knowledge }\end{array}$ & 3.054 & 1.145 & Moderate High \\
Waste Management & 2.940 & 1.095 & Moderate Low \\
Extinction of Plant & 2.847 & 1.171 & Moderate Low \\
River Care & 2.782 & 1.126 & Moderate Low \\
Behaviour & 2.750 & 1.465 & Moderate Low \\
& 2.907 & 0.912 & Moderate Low \\
\hline
\end{tabular}

Table 5. MANOVA analysis of the differences in environmental knowledge level \& behaviour based on education level.

\begin{tabular}{cccccccc}
\hline Group & N & $\begin{array}{c}\text { Wilks' } \\
\text { Lambda } \\
\text { Value }\end{array}$ & F Values & $\begin{array}{c}\text { DF } \\
\text { Between } \\
\text { Group }\end{array}$ & $\begin{array}{c}\text { DF Within } \\
\text { Group }\end{array}$ & $\begin{array}{c}\text { Significant } \\
\text { Level }\end{array}$ & $\begin{array}{c}\text { Partial } \\
\text { n2 }\end{array}$ \\
\hline $\begin{array}{c}\text { Secondary } \\
\text { School Student } \\
\text { Primary }\end{array}$ & 188 & 0.939 & 9.227 & 3 & 424 & 0.000 & 0.061 \\
$\begin{array}{c}\text { School Student } \\
\text { Schol }\end{array}$ & 240 & & & & & & \\
\hline
\end{tabular}

Table 6. Test of between-subject effects on knowledge \& behaviour construct.

\begin{tabular}{rccc}
\hline Construct & F Value & Significant Level (p) & Partial n2 \\
\hline Knowledge & 23.219 & $0.000^{*}$ & 0.052 \\
Behaviour & 2.103 & 0.148 & 0.005 \\
Significant level at $\mathbf{0 . 0 5 ^ { * }}$ & & & \\
\hline
\end{tabular}

\subsection{Differences in Environmental Knowledge Level \& Behaviour Based on Gender}

Table 7 shows the findings of MANOVA's analysis of the differences in knowledge and behaviour constructs between male and female students. The findings show that there is no difference in mean score for environmental literacy construct as a whole based on the gender, where the values of Wilks' Lambda $=$ $0.991 ; \mathrm{F}=1.219$ and $\mathrm{p}=0.302(\mathrm{p}>0.05)$, partial eta squared $(\mathrm{n} 2)=0.009$.

\subsection{Difference of Knowledge Level and Behaviour on Environmental Care Practices Based on Tribes}

Table 8 shows the findings of MANOVA's analysis of the differences in knowledge and behaviour constructs between students of the Proto Malay, Senoi and Negrito tribes. The findings show that there is a significant difference in the overall mean score based on the tribe where Wilks' Lambda $=0.918 ; \mathrm{F}(3,424)=$ 12.572 and $\mathrm{p}=0.000(\mathrm{p}>0.05)$, and partial eta squared $\mathrm{n} 2=0.082$. 
Table 7. MANOVA's analysis of the differences in Knowledge and Behaviour constructs based on Gender

\begin{tabular}{cccccccc}
\hline Group & N & $\begin{array}{c}\text { Wilks' } \\
\text { Lambda } \\
\text { Value }\end{array}$ & F Values & $\begin{array}{c}\text { DF } \\
\text { Between } \\
\text { Group }\end{array}$ & $\begin{array}{c}\text { DF Within } \\
\text { Group }\end{array}$ & $\begin{array}{c}\text { Significant } \\
\text { Level }\end{array}$ & $\begin{array}{c}\text { Partial } \\
\text { n2 }\end{array}$ \\
\hline Male & 200 & 0.991 & 1.219 & 3 & 424 & 0.302 & 0.009 \\
Female & 228 & & & & & & \\
\hline
\end{tabular}

Table 8. MANOVA's analysis of the differences in Knowledge and Behaviour constructs based on Tribes.

\begin{tabular}{cccccccc}
\hline Group & N & $\begin{array}{c}\text { Wilks' } \\
\text { Lambda } \\
\text { Value }\end{array}$ & F Values & $\begin{array}{c}\text { DF } \\
\text { Between } \\
\text { Group }\end{array}$ & $\begin{array}{c}\text { DF Within } \\
\text { Group }\end{array}$ & $\begin{array}{c}\text { Significant } \\
\text { Level }\end{array}$ & $\begin{array}{c}\text { Partial } \\
\text { n2 }\end{array}$ \\
\hline $\begin{array}{c}\text { Proto-Malay } \\
\text { Senoiand } \\
\text { Negrito }\end{array}$ & 231 & 0.918 & 12.572 & 3 & 424 & 0.000 & 0.082 \\
\hline
\end{tabular}

After obtaining significant results in the multivariate test, the Test of between-subject effects was referred and the results of the analysis showed a repeated comparison. To reduce the error of type 1 due to repeated analysis, Alpha Bonferroni modification method has been used (Hair et al., 2010). Table 9 shows a significant difference based on Alpha Bonferroni leve $(0.05 / 2)=0.025$ in knowledge constructs (Valve $\mathrm{F}=23.944, \mathrm{p}=0.00$, partial eta squared $(\mathrm{n} 2)=$ 0.066. The mean score for environmental knowledge found that students from the Proto-Malay tribe scored higher than the Senoi and Negrito tribe students. However, there was no significant difference in the constructs of environmental care behaviours based on tribes, $(\mathrm{F}=1.887, \mathrm{p}=0.170$, partial eta squared $(\mathrm{n} 2)=$ $0.04)$.

\section{Discussion}

This section which is closely related to the preceding sections, provides answers to the research questions by highlighting the findings which emerged from the Findings section. However, because of the complexities of the findings that emerged, they will not be discussed in a simple, straightforward linear fashion; rather, key issues will be discussed in an integrated way within this section. The section begins by discussion issues related to environmental knowledge before behaviour towards environmental care is provided.

\subsection{Environmental Knowledge}

The level of environmental knowledge among Malaysian Aboriginal people is at a moderate level. This findings confirm previous studies which argue that most Aboriginal students already possess indigenous knowledge (IK) on environmental conservation and preservation, nonetheless they are not interested to follow formal EE curriculum at school (Mallen, Barrazab, Bodenhornc, \& Garcia, 2009). Investigating this matter further, it is interesting to note that, their 
Table 9. Test of between-subject effects based on tribes in relation to knowledge \& behaviour constructs.

\begin{tabular}{cccc}
\hline Construct & F Value & Significant Level (p) & Partial n2 \\
\hline Knowledge & 23.944 & $0.000^{*}$ & 0.066 \\
Behaviour & 1.887 & 0.170 & 0.004 \\
Significant level at $\mathbf{0 . 0 1 7 ^ { * }}$ & & & \\
\hline
\end{tabular}

weaknesses in understanding science concept which lead to failing in examination has caused them to avoid formal EE curriculum (Yusuf, Ibrahim, Sulaiman, \& Mamat, 2005).

As a result, the level of environmental knowledge among Aboriginal people is at a low level. According to Abdul Razaq et al., although Aboriginal students scored poorly in IQ test, this does not mean that their IQ is lower. The researchers added, many factors could possibly lead to this for example, language barriers where they are unable to understand the scientific terms and vocabularies commonly used by other communities. Nevertheless, the environmental action knowledge among Aboriginal students is at a good level which indicates that they are aware of how to take appropriate action in situations that involve decision-making to overcome environmental problems.

Furthermore, the level of environmental knowledge among secondary and primary school students indicates that preceding group of students possess a higher level of environmental knowledge than latter group. This means that the level of environmental knowledge increases parallel to the age and schooling level (Anderson, Teisl, Criner, Tisher, Smith, Hunter, Norton, Jelli-son, Alyokkin, Galland, Haggard, \& Bicknell, 2007; Ismail, 2005).

The findings also show that there is no difference in the level of environmental knowledge between male and female students. This finding is consisted with the findings of Ismail (2005) and Department of Orang Asli Development (DOAD) (2009) which shows that there is no significant difference between male and female students in terms of environmental knowledge. However, this finding is contrary to the findings of the study by Ismail (2005)) and Tikka, Kuitunen, \& Tynys (2000) who found that male students had higher environmental knowledge but female students showed more concern for the environmental care and are more willing to change their behaviour in preserving the environment.

The difference in the level of environmental knowledge based on tribes shows that students from the Proto-Malay tribe have the highest level of environmental knowledge compared to other tribe groups. This is mainly because the lifestyle of the Proto-Malay tribe is more alike the Malays in terms of their language and cultural characteristics (Jelas, Ahmad, \& Ayudin, 2009), and they are more advanced and open to modernization to compared to other tribes. The available infrastructure and facilities at Proto-Malay village could possibly increased their 
levels of environmental knowledge. This view is in line with (Kollmuss \& Agyeman, 2002) opinion which claims that facilities such as recycling bins, socio-economic status, social influences, and accessible information resources can significantly influence one's knowledge and behaviour toward the environment.

\subsection{Behaviour towards Environmental Care}

The findings show that the behaviours of Aboriginal students towards environmental care are at low moderate level. Aboriginal students most often practices behaviour related to preventing the extinction of animal species. They are most concerned with the care of animal species most probably because they used to hunt animals for their own needs and for commercial purposes.

Facilities such as recycling bins and garbage disposal centres in their settlements do not change the students' behaviour in managing solid waste responsibly. Practical and relevant behaviours to prevent the extinction of plant species also are less exercised by Aboriginal students as they are not practicing traditional farming systems anymore due to RPS initiatives. After RPS was launched, the community of Aboriginal people was transferred to one area and was taught to practice modern farming system.

As a result, the behaviour of students in preventing and conserving plant species from extinction is at low moderate level. Furthermore, the clean tab water supply received by Aboriginal people has made them less concerned with river care compared to the old times where river was their main source of water.

\section{Conclusion}

In order to enhance Aboriginal people's environment, researchers propose some suggestions to guide responsible stakeholders in producing environmentally literate citizen. Among them are teachers need to plan a fun learning approach in delivery EE curriculum by integrating outdoor learning, hands-on, experiential, role-play, simulation, and activity-based approaches which are appropriate to Aboriginal people needs and context. As EE is closely related to science subjects, EE teachers need to collaborate actively with science teachers in planning effective pedagogical strategies that enable Aboriginal students to understand the basic concepts of science.

Most importantly, the Ministry of Education should revise the pre-service teacher training curriculum to include comprehensive and holistic training on how teachers can creatively integrate IK and funds of knowledge to improve citizen's awareness, knowledge and attitude towards environmental conservation and preservation.

\section{Acknowledgements}

This paper was funded by DPP-2018-001, Universiti Kebangsaan Malaysia. 


\section{Conflicts of Interest}

The authors declare no conflicts of interest regarding the publication of this paper.

\section{References}

Anderson, M. W., Teisl, M., Criner, G., Tisher, S., Smith, S., Hunter, M., Norton, S. A., Jellison, J., Alyokkin, A., Galland, T. E., Haggard, S., \& Bicknell, E. (2007). Attitude Changes of Undergraduate University Students in General Education Courses. The Journal of General Education, 56, 149-158. https://doi.org/10.1353/jge.2007.0016

Aziz, M. F. (2008). Erratic Weather. Global Warming. Estidotmy, 76, 14-15.

bin Ab Hadi, M. Y., bin Mohd Yunos, J., \& bin Esa, A. (2003). National Seminar Proceeding of Environmental Management. Bangi: National University of Malaysia.

Chopil, T. Y., \& Hunt, B. T. W. (2009). Aboriginals and Environment. http://www.perakspeak.com/

Department of Environment (2007). National Policy on Environment. http://www.kats.gov.my/ms-my/Pages/default.aspx

Department of Orang Asli Development (DOAD) (2009). http://www.jakoa.gov.my/org-asli/

Elder, J. L. (2003). A Field Guide to Environmental Literacy: Making Strategic Investment in Environmental Education. Environmental Education Coalition.

Emmons, K. M. (1997). Perspectives on Environmental Action: Reflection and Revision through Practical Experience. The Journal of Environmental Education, 29, 34-44. https://doi.org/10.1080/00958969709599105

Goldman, D., Yavetz, B., \& Pe'er, S. (2006). Environmental Literacy in Teacher Training in Israel: Environmental Behaviour of New Students. The Journal of Environmental Education, 38, 3-22. https://doi.org/10.3200/JOEE.38.1.3-22

Haliza, A. R. (2010). The Involvement of Aboriganal Community in Issues Related to the Environment: Survey on Mah MeriPulau Carey, Kuala Langat, Selangor. Kemanusiaan, 17, 114-134.

Hines, J. M., Hungerford, H. R., \& Tomera, A. N. (1986/1987). Analysis and Synthesis of Research on Responsible Environmental Behavior: A Meta-Analysis. Journal of Environmental Education, 18, 1-8. https://doi.org/10.1080/00958964.1987.9943482

Hood, S. (2012). Dignifying the Aboriginal Research in Malaysia. Bangi: Publisher National University of Malaysia.

Hungerford, H. R., \& Volk, T. L. (1990). Changing Learner Behaviour through Environmental Education. Journal of Environmental Education, 21, 8-22. https://doi.org/10.1080/00958964.1990.10753743

Hungerford, H. R., Bluhm, W. J., Volk, T. L., \& Ramsey, J. M. (2005). The Tbilisi Declaration. Essential Readings in Environmental Education (3rd ed.). Champaign, IL: Stripes Publishing.

Ismail, H. (2005). The Level of Environmental Awareness among the Secondary School Students of Jerantut District, Pahang. Master Research Project, Selangor: National University of Malaysia.

Ismail, N. A. (2004). Awareness of Students about the Environmental Education (EE) in the Geography Curriculum. Master Research Project. Kuala Lumpur: University of Malaya. 
Jelas, Z. M., Ahmad, A. R., \& Ayudin, A. R. (2009). The Perspective of Aboriginal Historiology in Peninsular Malaysia. The Aboriginal Community: Educational and Sociocultural Perspectives. Bangi: National University of Malaysia.

Kollmuss, A., \& Agyeman, J. (2002). Mind The Gap: Why Do People Act Environmentally and What Are the Barriers to Environmental Behaviour? Environmental Educational Research, 8, 239-260. https://doi.org/10.1080/13504620220145401

Mallen, I. R., Barrazab, L., Bodenhornc, B., \& Garcia, V. R. (2009). School and Local Environmental Knowledge, What Are the Links? A Case Study among Indigenous Adolescents in Oaxaca, Mexico. International Research in Geographical and Environmental Education, 18, 82-96. https://doi.org/10.1080/10382040902861155

Mian, L. H. (1997). Nutritional Status and Reproductive Health of Aboriginal Women. Undergraduate Research Projects. Serdang: Universiti Putra Malaysia.

Ministry of Education, Malaysia (1998). Guide to Environmental Education Teachers across KBSM Curriculum. Kuala Lumpur: Curriculum Development Centre.

Nicholas, C., \& Lasimbang, J. (2004). Biodiversity \& Indegenous Knowledge System in Malaysia. Subang Jaya: Centre for Aboriginal Concern.

Nunnally, J. C. (1997). The Study of Change Evaluation Research: Principle Conserning Measurement Experimental Design and Analysis. In E. L. Dlm. Struening, \& M. Guttentag (Eds.), Handbook of Evaluation Research. Beverly Hills: Sage.

Palmer, J. A. (1998). History and Development of Environmental Education. Environment Education in the 21st Century. Theory, Practice, Progress and Promise. London: New Fatter Lane.

Ramsey, C. E., \& Rickson, R. E. (1976). Environmental Knowledge and Attitudes. The Journal of Environmental Education, 8, 10-18. https://doi.org/10.1080/00958964.1976.9941552

Stapp, W. B. (1969) The Concept of Environmental Education. The Journal of Environmental Education, 1, 30-31. https://doi.org/10.1080/00139254.1969.10801479

Tikka, P. M., Kuitunen, T. M., \& Tynys, S. M. (2000). Effects of Educational Background on Students' Attitudes, Activity Levels, and Knowledge Concerning the Environment. Journal of Environmental Education, 31, 12-19. https://doi.org/10.1080/00958960009598640

United Nations (1992). Agenda 21 Chapter 36. http://www.un-documents.net/a21-36.htm

Yusuf, N., Ibrahim, N. I., Sulaiman, R., \& Mamat, R. (2005). Survey on the Environmental Knowledge and Awareness among Aboriginal Students: National Seminar Proceeding of Environmental Managemant. Bangi: National Universityof Malaysia. 